\title{
Tip 1 Diyabetes Mellituslu Olguların Tanı ve Tedavilerinin Retrospektif Değerlendirilmesi
}

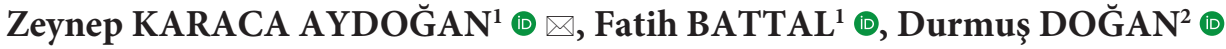 \\ ${ }^{1}$ Çanakkale Onsekiz Mart Üniversitesi Tıp Fakültesi, Çocuk Sağlığı ve Hastalıkları Anabilim Dalı, Çanakkale, Türkiye \\ ${ }^{2}$ Çanakkale Onsekiz Mart Üniversitesi Tıp Fakültesi, Çocuk Sağlığı ve Hastalıkları Anabilim Dalı, Çocuk Endokrinoloji Bilim Dalı, \\ Çanakkale, Türkiye
}

Bu makaleye yapılacak atıf: Karaca Aydoğan Z ve ark. Tip 1 Diyabetes Mellituslu Olguların Tanı ve Tedavilerinin Retrospektif Değerlendirilmesi. Turk J Diab Obes 2021;2: 111-117.

ÖZ

Amaç: Çanakkale ili ve çevresindeki Tip 1 Diabetes Mellitus (T1D) tanılı olguların demografik özelliklerinin, klinik ve laboratuvar bulgularının, başvuru anında diyabetik ketoasidoz (DKA) durumlarının ve aldıkları tedavilerin değerlendirilmesi amaçlanmıştır.

Gereç ve Yöntemler: Çanakkale Onsekiz Mart Üniversitesi Tıp Fakültesi Hastanesi Çocuk Sağlığı ve Hastalıkları kliniğine 01.04.201101.04.2019 tarihleri arasında en az bir kez başvurmuş 0-18 yaş arası, 165 DM tanılı hasta dosyası retrospektif tarandı. Dosya kayıtları eksik 68 hasta, Tip 2 DM tanılı dört hasta, Gençlerde Görülen Erişkin Tipi Diyabet (MODY) tanılı bir hasta olmak üzere 73 hasta çalışma dışı bırakıldı, 92 hasta çalışmaya alındı.

Bulgular: Olgularımızın \%54,35’i kız, ortalama tanı yaşı 7,6 $\pm 3,9$ yaş idi. En sık tanı alınan mevsimler sonbahar (\%32,6) ve kış (\%30,43) oldu. Olgularımızın \%52,17'sinin merkeze 0-50 km, \%42,39'unun 50-100 km, \%3,27'sinin 100-150 km, \%2,17'sinin ise 150 km'den daha uzak mesafede olduğunu tespit ettik. Diyabetik ketoasidoz ile başvuran olgularımızı hafif, orta ve ağır DKA olarak sınıflandırarak, tedavilerinde uygulanan protokollere göre DKA’dan çıkış sürelerini kıyasladığımızda, her üç grupta da Uluslararası Çocuk ve Ergen Diyabet Derneği (ISPAD) 2018 protokolü uygulanan olguların DKA’dan daha kısa sürede çıktığını saptadık.

Sonuç: Tip 1 diyabetiklerde DKA, hiperglisemi gibi akut ve retinopati, nefropati, nöropati, ateroskleroz gibi kronik komplikasyonlar görülebildiği için tanı ve takip önemlidir. Hastalığın bölgesel özelliklerinin araştırılması, etiyolojide önemli yer tutan genetik ve çevresel faktörler açısından yol göstericidir. Bizim çalışmamız Güney Marmara bölgesinde çocukluk çağı yaş grubunda T1D tanısı ile takip edilen olguların incelendiği ilk çalışmalardan biridir. Tespit ettiğimiz bulgular yapılan benzer çalışmaların sonuçları ve literatürle uyumludur.

Anahtar Sözcükler: Tip 1 diabetes mellitus, Hiperglisemi, Diyabetik ketoasidoz

\section{Retrospective Evaluation of Diagnosis and Treatment of Patients with Type 1 Diabetes Mellitus}

\begin{abstract}
Aim: It was aimed to evaluate the demographic characteristics, clinical and laboratory findings, diabetic ketoacidosis (DKA) status at the time of admission and the treatments in patients with Type 1 Diabetes Mellitus (DM) in and around Çanakkale.

Material and Methods: The files of 165 DM patients, aged 0-18 years, who applied to Çanakkale Onsekiz Mart University Medical Faculty Hospital Pediatrics Clinic between 01.04.2011-01.04.2019 at least once, were retrospectively reviewed. 73 patients, including 68 patients with incomplete file records, 4 patients with Type 2 DM, 1 patient diagnosed with Adult Type Diabetes in the Youth (MODY), were excluded, 92 patients were included in the study.

Results: $54.35 \%$ of our cases were girls, mean age at diagnosis was $7.6 \pm 3.9$ years. The seasons with the most frequent diagnosis were autumn (32.6\%) and winter (30.43\%). 52.17\% of the cases resided within $0-50 \mathrm{~km}$ of the city center, $42.39 \%$ within $50-100 \mathrm{~km}, 3.27 \%$ within $100-150 \mathrm{~km}$ and $2.17 \%$ further than $150 \mathrm{~km}$. When we classified our patients who presented with diabetic ketoacidosis as mild, moderate and severe DKA and compared the time to exit from DKA according to the protocols applied in their treatment, we found that the patients who were applied the International Child and Adolescent Diabetes Association (ISPAD) 2018 protocol were removed from DKA in a shorter time.
\end{abstract}

ORCID: Zeynep Karaca Aydoğan / 0000-0002-2894-026X, Fatih Battal / 0000-0001-9040-7880, Durmuş Doğan / 0000-0001-5369-8797 
Conclusion: Since acute complications such as DKA, hyperglycemia and chronic complications such as retinopathy, nephropathy, neuropathy, and atherosclerosis can be seen in patients with type $1 \mathrm{DM}$, diagnosis and follow-up are important. Investigation of the regional characteristics of the disease is guiding in terms of genetic and environmental factors that have an important place in etiology. Our study is one of the first studies investigating the cases followed up with the diagnosis of Type 1 DM in the childhood age group in the South Marmara region. Our findings are consistent with the results of similar studies and the literature.

Keywords: Type 1 DM, Hyperglycemia, Diabetic ketoacidosis

\section{Gíriș}

Tip 1 diabetes mellitus, pankreas beta hücrelerinin otoimmün veya non-otoimmün nedenlerle yıkımı sonucu, insülin eksikliği ve hiperglisemi ile sonuçlanan, çocuk ve adölesanlarda en sık görülen diyabet türü olmakla beraber, bu yaş grubunun en sık kronik hastalığıdır. Genetik yatkınlığa sahip bireylerde, çevresel etkenler ve otoimmün faktörlerin de etkisiyle hastalık gelişir ve hastalar kalıcı insülin yokluğu nedeniyle insülin takviyesine ihtiyaç duyarlar (1). Tanı yaşında; okula başlama döneminde enfeksiyöz ajanlara maruz kalınması sonucu hastalık sıklığının artmasıyla 5-7 yaş döneminde birinci zirve, puberteyle beraber artan gonadal steroidler ve büyüme hormonu sekresyonunun tetiklemesiyle 10-14 yaş döneminde ikinci zirve görülür (2). Uluslararası Diyabet Federasyonu'nun ("International Diabetes Federation", IDF) 2019 yılında yayınladığı dokuzuncu IDF Diyabet Atlası verilerine göre; 20 yaş altında mevcut 1.110.100 çocuk ve ergen T1D tanılıdır ve her yil 128.900 yeni hasta tanı almaktadır (3). Tip 1 diabetes mellitus coğrafi konumlara, ülkelere, hatta şehirlere göre farklılık gösterebilir (4).

Bu tür veriler hastalığı etkileyen faktörler açısından değerli bilgiler sunmaktadır. Bu çalışmamızda Güney Marmara bölgesinde kliniğimize başvuran T1D tanılı hastaların demografik, klinik ve laboratuvar özelliklerinin, tanı alma sürecinin, tanı anında eşlik eden komplikasyonların araştırılmasını amaçladık.

\section{GEREÇ ve YÖNTEMLER}

Çanakkale Onsekiz Mart Üniversitesi Tip Fakültesi Klinik Araştırmalar Etik Kurulundan 08.05.2019 tarihli 2011KAEK-27/2019-1900054816 sayılı onay alındı. Hastanemizin Çocuk Sağlığı ve Hastalıkları kliniğine 01.04.201101.04.2019 tarihleri arasında en az bir kez başvurmuş, 0-18 yaş arası 165 diabetes mellitus tanılı hastanın dosyaları retrospektif tarandı. Dosya kayıtları eksik olan 68 hasta, tip 2 diabetes mellitus (T2D) tanılı dört hasta, MODY tanılı bir hasta olmak üzere 73 hasta çalışma dışı bırakıldı. Diğer hastalar cinsiyet ayırt edilmeksizin çalışmaya dahil edildi.

Olguların tanı yaşları [0-8 yaş (prepubertal), 9-12 yaş (pubertal), 13-18 yaş (adölesan)], cinsiyet, antropometrik ölçüm ve güncel yaşları, yaşadığı yerlerin merkeze olan uzaklıkları belirlendi. Olguların tanı aldığı mevsimler, başvuru anındaki şikayetleri, başvuru şikayetlerinin yaş gruplarına göre dağglımı, hastaneye başvuru öncesindeki semptom süresi belirlendi. Otoimmün tiroidit tanıs1, serbest tiroksin (sT4) düşük, tiroid stimulan hormon (TSH) ve anti tiroglobulin (anti-TG) ve anti tiroid peroksidaz (anti-TPO) yüksekliği ile konuldu (5). Çölyak hastalığı tanısında Antigliadin antikor (AGA) IgA ve IgG, Antiendomisyum antikor (EMA) IgA ve IgG kullanıldı (6). Diyabetik ketoasidoz ile başvuran olguların yüzdesi, yaş grubu ve cinsiyete göre dağılımı ve DKA tedavisinde uygulanan protokoller belirlendi, protokollere göre DKA'dan çıkış süreleri karşılaştırıldı. Diyabetik ketoasidoz tanısı için biyokimyasal kriterler; kan şekerinin $200 \mathrm{mg} / \mathrm{dL}$ üzerinde olması, venöz pH'nın 7,30'dan düşük olması veya serum bikarbonat düzeyinin $15 \mathrm{mmol} / \mathrm{L}$ 'den düşük olması, kan beta-hidroksibütirat (BOHB) düzeyinin $3 \mathrm{mmol} / \mathrm{L}$ 'nin üzerinde olması veya ketonüri görülmesi olarak alındi. Venöz $\mathrm{pH}<7,30$ veya serum bikarbonat düzeyi $<15 \mathrm{mmol} / \mathrm{L}$ olanlar hafif, venöz $\mathrm{pH}<7,20$ veya serum bikarbonat düzeyi $<10 \mathrm{mmol} / \mathrm{L}$ olanlar orta, venöz $\mathrm{pH}<7,10$ veya serum bikarbonat düzeyi $<5 \mathrm{mmol} / \mathrm{L}$ olanlar ağır DKA olarak sınıflandırıldı (7). Olguların başvuru anında laboratuvar bulguları belirlendi. DKA ile başvuran ve başvurmayanlar olarak iki gruba ayrılarak; tanı anındaki kan glukoz düzeyi, serum C-peptid, HbA1c ve insülin değerleri karşılaştırıldı. Tanı anında uygulanan DKA tedavi protokolleri ve hastaların DKA'dan çıkış süreleri (saat) belirlendi. Metabolik kontrol durumunu değerlendirmek için son bir yılda, üç aylık aralıklarla bakılan HbA1c ortalaması $<\% 7,5$ iyi metabolik kontrol, > \%7,5 kötü metabolik kontrol lehine değerlendirildi (8). Olguların yaşadıkları yerlerin merkeze uzaklıkları ve metabolik kontrol arasındaki ilişki karşılaştırıldı. Elde edilen bütün veriler veri kayıt formuna kaydedildi.

\section{İstatistiksel Analiz}

Veriler Statistical Package for the Social Sciences; Sosyal Bilimler İçin İstatistik Programı (SPSS) Paket Program 20.0 sürümü ile analiz edildi. Tanımlayıcı verilerin sunumunda say1, yüzde, ortalama, ortanca, standart sapma, minimum, maksimum kullanıldı. Kategorik değişkenlerin karşılaştırılmasında Ki Kare Testi kullanıldı. Verilerin normal dağılıma uygunluğu Shapiro Wilk Testi ile değerlendirildi. Normal dağılıma uyan değişkenlerin karşılaştırılmasında İki Ortala- 
ma Arasında Farkın Önemlilik Testi ve Tek Yönlü ANOVA Testi, uymayan değişkenlerin karşılaştırılmasında Mann Whitney U Testi ve Kruskal Wallis Testi kullanıldı. İstatiksel anlamlılık için $\mathrm{p}<0,05$ kabul edildi.

\section{BULGULAR}

Olguların \%54,35'i kı cinsiyette, ortalama tanı yaşı $7,61 \pm 3,91$ yaş olarak bulundu. Olguların \%56,51'inin 0-8, \%35,88'inin 9-12, \%7,61'inin 13-18 yaş aralığında tanı aldığını saptadık. Güncel demografik özelliklere bakıldığında; yaş ortalaması $11,13 \pm 3,89$ yll, boy ortalaması $143,03 \pm 21,50$ cm, vücut ağırlığı ortalaması 40,68 $\pm 17,88 \mathrm{~kg}$, Vücut Kütle İndeksi (VKİ) ortalaması 19,16 $\pm 3,62 \mathrm{~kg} / \mathrm{m}^{2}$, VKİ yüzdelik ortalaması $61,65 \pm 24,57$ olarak saptandı (Tablo 1). En sık tanı alınan mevsimler sonbahar $(\% 32,60)$ ve kış $(\% 30,43)$ mevsimi oldu (Şekil 1). Yaşadıkları yerlerin merkeze uzaklıklarına göre $>150 \mathrm{~km}$ üstü mesafede uzaklığı olan hastaların oranı \%2,17 idi (Tablo 2).Tüm yaş gruplarında en sık başvuru nedeni $\% 78,26$ ile poliüri ve $\% 71,73$ ile polidipsi olarak saptandı (Şekil 2). Olguların \%54,34'ünün DKA ile başvurduğu tespit edildi. DKA ile başvuran ve başvurmayan olgular yaş grubu ve cinsiyet dağılımına göre incelendiğinde cinsiyet ve yaş grupları arasında anlamlı fark saptanmadı $(\mathrm{p}=0,117)(\mathrm{p}=1,0)$. Olguların tanı öncesi ortalama semptom süresi $35,28 \pm 56,27$ gün olarak bulundu. $\mathrm{Bu}$ sürenin yaş gruplarına göre dağılımı incelendiğinde,

Tablo 1: Güncel demografik özellikler.

\begin{tabular}{lcc}
\hline & \multicolumn{2}{c}{ T1D $(\mathbf{n = 9 2 )}$} \\
\hline & Ortalama \pm ss & Ortanca (min-max) \\
\hline Yaş (yıl) & $11,13 \pm 3,89$ & $11,75(2,0-18,0)$ \\
\hline Boy $(\mathrm{cm})$ & $143,03 \pm 21,50$ & $146,50(80,0-183,0)$ \\
\hline Vücut Ağırlığ $(\mathrm{kg})$ & $40,68 \pm 17,88$ & $37,50(10,60-86,00)$ \\
\hline VKİ $\left(\mathrm{kg} / \mathrm{m}^{2}\right)$ & $19,16 \pm 3,62$ & $18,20(13,60-29,80)$ \\
\hline VKİ yüzdelik & $61,65 \pm 24,57$ & $64,75(7,0-99,0)$ \\
\hline
\end{tabular}

ss: Standart sapma, cm: Santimetre, kg: Kilogram, VKİ: Vücut Kütle İndeksi, $\mathbf{m}^{2}$ : Metrekare

Tablo 2: Olguların yaşadıkları yerlerin merkeze uzaklıkları.

\begin{tabular}{lc}
\hline & T1D (n=92) \\
\cline { 2 - 2 } & Olgu sayısı [n(\%)] \\
\hline $0-50 \mathrm{~km}$ & $54(58,71)$ \\
\hline $50-100 \mathrm{~km}$ & $33(35,86)$ \\
\hline $100-150 \mathrm{~km}$ & $3(3,26)$ \\
\hline$>150 \mathrm{~km}$ & $2(2,17)$ \\
\hline Toplam & $\mathbf{9 2 ( 1 0 0 )}$ \\
\hline
\end{tabular}

km: Kilometre istatistiksel olarak anlamlı fark bulunmadı $(\mathrm{p}=0,924)$. Yine bu sürenin cinsiyete göre dağılımı incelendiğinde anlamlı fark bulundu $(\mathrm{p}=0,016)$. Olguların \%4,35'inde hipotiroidi, \%1,09'unda çölyak hastalı̆̆ı $\% 1,09$ 'unda Hashimoto tiroiditi olmak üzere, toplam altı olguda $(\% 6,52)$ otoimmün hastalık eşlik ettiği tespit edildi. Olguların tanı anında kan

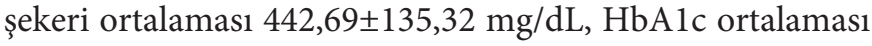
$\% 11,23 \pm 2,53$, C-peptid ortalaması $0,58 \pm 0,95 \mathrm{ng} / \mathrm{mL}$, insülin ortalaması 4,56 $\pm 5,29 \mathrm{uIU} / \mathrm{mL}$ saptandı. Tanı anında bakılan $\mathrm{HbA1c}$ değerlerinin cinsiyet ve yaş gruplarına göre karşılaştırilmasinda anlamlı fark saptanmadı $(\mathrm{p}=0,988) \quad(\mathrm{p}=0,716)$. Hastaneye başvuru anında DKA olan ve DKA olmayanlar arasında $\mathrm{HbAlc}$ ve C-peptid değerleri açısından anlamlı fark bulundu $(\mathrm{p}<0,001)$ (Tablo 3$)$. Son bir yıllık HbA1c ortalamaları hastaların $\% 19,56$ 'sında $\leq \% 7,5$ ve altındayd 1 ve iyi metabolik kontrol lehine değerlendirildi, \%80,44'ünde $>\%$ 7,5 üstünde ve kötü metabolik kontrol lehine değerlendirildi.

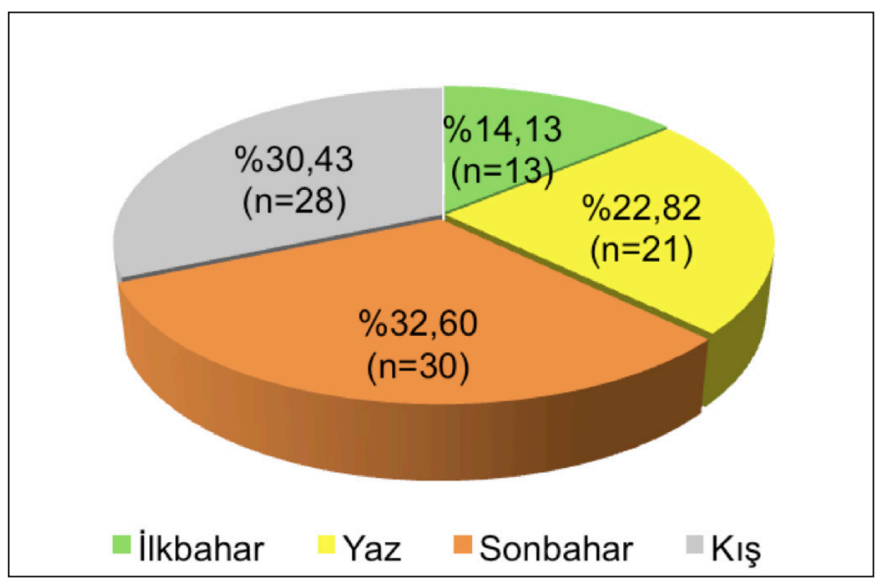

Şekil 1: Tanı mevsimine göre dağılım.

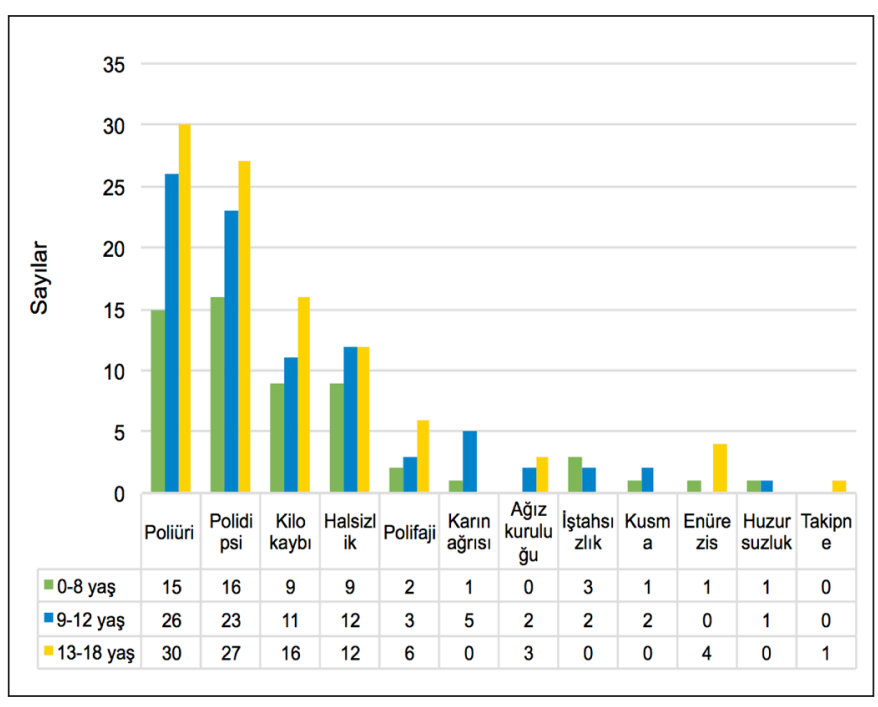

Şekil 2: Başvuru şikayetlerinin yaş grubuna göre dağılımı. 
Tablo 3: DKA ile başvuran ve DKA ile başvurmayanların biyokimyasal parametrelerinin karşılaştırılması.

\begin{tabular}{lccccc}
\hline \multicolumn{4}{c}{ DKA var $(\mathbf{n}=)$} & \multicolumn{2}{c}{ DKA yok $(\mathbf{n}=)$} \\
\hline & ortalama \pm ss & ortanca $($ min-maks) & ortalama \pm ss & ortanca (min-maks) & p \\
\hline Kan şekeri (mg/dL) & $457,68 \pm 120,46$ & $460,50(175,0-793,0)$ & $421,52 \pm 153,27$ & $390,0(200,0-850,0)$ & 0,111 \\
\hline HbA1c $(\%)$ & $12,0 \pm 2,24$ & $12,0(7,10-17,80)$ & $9,96 \pm 2,49$ & $10,10(5,50-15,40)$ & $\mathbf{0 , 0 0 1}^{*}$ \\
\hline C-peptid $(\mathbf{n g} / \mathbf{m L})$ & $0,32 \pm 0,30$ & $0,20(0,10-1,40)$ & $0,96 \pm 1,37$ & $0,45(0,10-6,50)$ & $\mathbf{0 , 0 0 1}$ \\
\hline İnsülin $(\mathbf{u I U} / \mathbf{m L})$ & $3,33 \pm 2,42$ & $2,0(0,20-10,50)$ & $6,31 \pm 7,46$ & $2,65(0,20-31,0)$ & 0,236 \\
\hline
\end{tabular}

ss: Standart sapma, mg: Miligram, dL: Desilitre, HbAlc: Glikolize hemoglobin, ng: Nanogram, mL: Mililitre, uIU: Mikro internasyonel ünite, p: Mann Whitney U Testi, $\mathbf{p}^{*}$ : İki Ortalama Arasında Farkın Önemlilik Testi

Tablo 4: Merkeze uzaklık ve metabolik kontrol arasındaki ilişki.

\begin{tabular}{lcc}
\hline & Metabolik Kontrol Durumu (Yüzdeler) \\
\hline & İyi (HbA1c $<\% 7,5)$ & Kötü $($ HbA1c $>$ \%7,5) \\
\hline $0-50 \mathrm{~km}$ & 22,23 & 77,77 \\
\hline $50-100 \mathrm{~km}$ & 15,16 & 84,84 \\
\hline $100-150 \mathrm{~km}$ & 33,34 & 66,66 \\
\hline$>150 \mathrm{~km}$ & - & 100 \\
\hline
\end{tabular}

km: Kilometre

Tablo 5: Diyabetik ketoasidoz tedavisinde kullanılan tedavi protokolleri.

\begin{tabular}{lc}
\hline Tedavi protokolleri & Olgu sayıs1 $\mathbf{n}(\mathbf{\%})$ \\
\hline ISPAD 2009 & $6(12,0)$ \\
\hline ÇAYD 2017 & $8(16,0)$ \\
\hline ÇEDD 2016 & $9(18,0)$ \\
\hline ISPAD 2014 & $9(18,0)$ \\
\hline ISPAD 2018 & $18(36,0)$ \\
\hline Toplam & Toplam 50 (100)
\end{tabular}

ISPAD: Uluslararası Çocuk ve Ergen Diyabet Derneği, ÇAYD: Çocuk Acil Tıp ve Yoğun Bakım Derneği, ÇEDD: Çocuk Endokrinolojisi ve Diyabet Derneği

Merkeze $150 \mathrm{~km}$ 'den daha uzakta yaşayan hastaların tamamının metabolik kontrolünün kötü olduğu, 0-50 km uzakta yaşayan hastaların ise $\% 77,77$ 'sinin metabolik kontrolünün kötü olduğu saptandı (Tablo 4).

Diyabetik ketoasidoz ile başvuran 50 olgunun altısında ISPAD 2009, sekizinde Çocuk Acil Tip ve Yoğun Bakım Derneği (ÇAYD) 2017, dokuzunda Çocuk Endokrinolojisi ve Diyabet Derneği (ÇEDD) 2016, dokuzunda ISPAD 2014, 18 'inde ise ISPAD 2018 tedavi protokolü uygulandığı tespit edildi (Tablo 5). Olgular DKA şiddetine göre hafif, orta ve ağır olarak sinıflandırılarak uygulanan tedavi protokollerine göre DKA'dan çıkış sürelerine bakıldığında ISPAD 2018 protokolü uygulanan hafif DKA vakalarının 18,4 saatte, orta

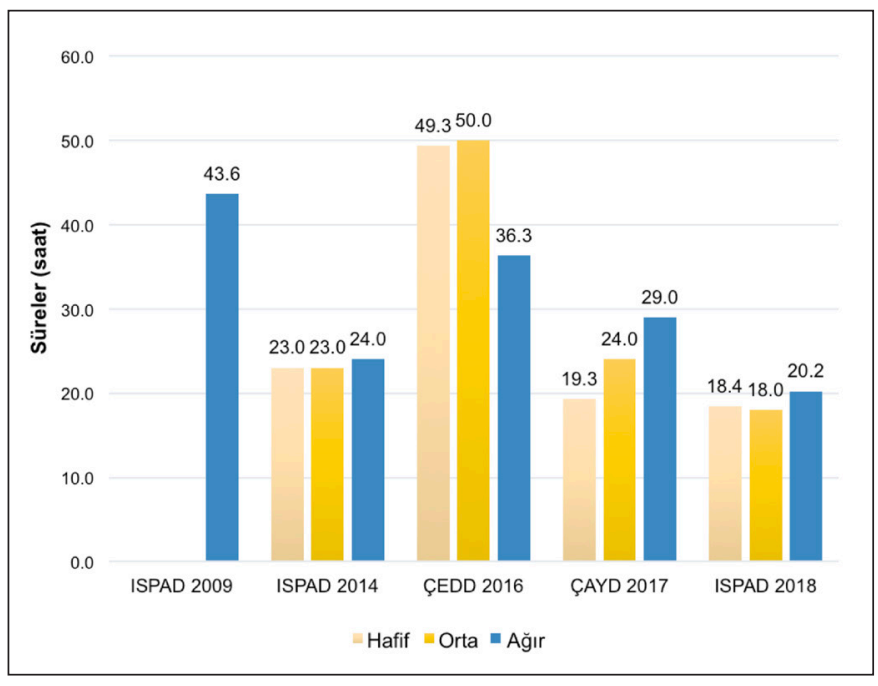

Şekil 3: Tedavi protokollerine ve DKA şiddetine göre DKA'dan çıkış süreleri (saat).

DKA vakalarının 18,0 saatte, ağır DKA vakalarının ise 20,2 saatte ketoasidozdan çıktığı ve bu sürelerin diğer protollere göre daha kısa olduğu saptandı (Şekil 3).

\section{TARTIȘMA}

Tip 1 diabetes mellitus tanısı nedeniyle Türkiye'nin Güney Marmara Bölgesinde takip edilen hastaların demografik, klinik ve laboratuvar özelliklerinin, tanı alma sürecinin, tanı anında eşlik eden komplikasyonların araştırılmasını amaçladığımız çalışmamızda olgularımızın \%54,35’inin kız cinsiyette olduğunu saptadık. Xin ve ark.'nın yaptıkları bir çalışmada olguların \%56,7'sinin kız cinsiyette olduğu saptanmıştır (9). Demir ve ark. tarafından yapılan bir çalışmada (10) olguların \%49,6'sı kız cinsiyette, Yeşilkaya ve ark. tarafından yapılan bir çalışmada (11) olguların \%50,6’i kız cinsiyette saptanmıştır. Verilerimiz diğer çalışmalara benzerdir.

Stipancic G. ve ark. tarafından yapılan bir çalışmada; en sık başvuru şikayetleri polidipsi $(\% 96,7)$ ve poliüridir $(\% 96,05)$ (12). Aras ve ark.'nın yaptığı bir çalışmada; en sık başvuru şikayetleri poliüri $(\% 83,8)$ ve polidipsi $(\% 83,8)$ olarak sap- 
tanmıştır (13). Çalışmamızda da tüm yaş gruplarında poliüri $(\% 77,17)$ ve polidipsi $(\% 71,73)$ en sik görülen başvuru şikayetleri olup bulgularımız literatürle uyumlu idi.

Tanı yaşı Usher-Smith ve ark.'nın yaptığı bir çalışmada $9,4 \pm 4,5$ yaş olarak saptanmıștır (14). Yeșilkaya ve ark. tarafından yapilan bir çalışmada ortalama tanı yaşı $10,6 \pm 4,6$ yaş, ve bunların \%14,8'inin 0-4, \%25,7'sinin 5-9, \%40,6'sinın 10-14, \%18,9'unun 15-18 yaş arasında olduğu tespit edilmiştir (11). Olgularımızın ortalama tanı yaşı 7,6 3 ,9 yaş olarak bulundu ve hastalığın görülme sıklığının birinci zirvesiyle uyumlu idi.

Zhao ve ark. tarafından yapılan bir çalışmada; sonbahar $(\% 15,2)$ ve yaz $(\% 14,1)$ aylarında artış hızının, kış $(\% 11,6)$ ve ilkbahar $(\% 10,9)$ aylarına göre daha yüksek olduğu saptanmıştır (15). Ülkemizde Güven ve ark.'nın yaptığ çalışmada, olguların ağırlıklı olarak sonbahar $(\% 30,7)$ ve kış $(\% 30,7)$ aylarında tanı aldığı gösterilmiştir $(16)$. Bizim çalışmamızda en sik tanı alınan mevsimler sonbahar $(\% 32,6)$ ve kış $(\% 30,43)$ oldu ve literatürle uyumlu bulundu. T1D'li olgular, enfeksiyonlara maruziyetin etkisi ile en sik sonbahar ve kış aylarında tanı sıklığı yüksek oranlardadır (17).

Klingensmith ve ark.'nın yaptıkları bir çalışmada; tanı anında DKA sıklığı \%34 olarak bulunmuştur (18). Demir ve ark.nın İzmir ve Manisa illerinde yaptığı bir çalışmada başvuru anında DKA sıklığı \%41 olarak bulunmuştur (19). Bizim çalışmamızda olguların \%54,34'ünün DKA ile başvurduğu saptandı ve yapılan diğer çalışmalarla benzer bir sonuca ulaşıldı. Dabelea ve ark. tarafından yapılan bir çalışmada; küçük yaş grubunda başvuru anında DKA görülme sıklığının, büyük yaş gruplarına göre daha yüksek olduğu gösterilmiştir (20). Bizim çalışmamızda; 0-8 yaş aralığındaki olguların \%71,43'ünün, 9-12 yaş aralığındaki olguların \%51,43'ünün, 13-18 yaş aralığındaki olguların \%47,22'sinin DKA ile başvurduğu gözlemlendi. Literatürle uyumlu olarak küçük yaş grubunda DKA ile başvurma yüzdesi daha yüksek saptandı fakat yaş grupları arasında istatistiksel olarak anlamlı fark bulunmadı. Küçük yaş gruplarında poliüri, polidipsi ve kilo kaybı belirtileri ailenin gözünden kaçabilir veya sağlık çalışanları tarafından DM lehine yorumlanmayabilir ve bu da DKA sıklığının küçük yaş gruplarında da sık görülmesini açlklayabilir (21).

Neu ve ark. tarafından yapılan bir çalışmada DKA sıklığ 1 kızlarda \%28,9, erkeklerde $\% 23,8$ olarak raporlanmıştır (22). Bizim çalışmamızda; DKA ile başvuran olguların \%54,0’ü kız, $\% 54,76$ 's 1 erkek cinsiyetteydi ve literatürle uyumlu idi. Cinsiyetler arasında istatistiksel olarak anlamlı fark saptanmadı.

Neu ve ark. tarafından yapılan bir çalışmada; tanı öncesi ortalama semptom süresi 15,2 gün bulunmuş, erkeklerde bu süre 13,4 gün, kızlarda ise 17,3 gün saptanmıştır. 0-4 yaş aralığında ortalama süre 11,2 gün, 5-9 yaş aralığında
14,7 gün, 10-14 yaş aralığında 18,3 gün olarak raporlanmış, büyük yaş gruplarında semptomların başlangıcı ile tanı arasındaki sürenin daha uzun olduğu saptanmıştır (23). Xin ve ark. tarafından yapılan bir çalışmada ise tanı öncesi ortalama semptom süresi 24,5 gün, 0-4 yaş aralığında ortalama 17,1 gün, 5-9 yaş aralığında 23,2 gün, 10-14 yaş aralığında 28,5 gün olarak saptanmıştır. Aynı çalışma; küçük çocuklarda otoimmün haraplanmanın daha hızlı gerçekleşmesinin, beta hücre rezervinin daha hızlı düşmesine neden olarak, metabolik bozulmanın diğer yaş gruplarına göre daha kısa sürede geliştiğini ve bu durumun küçük yaş grubunda semptom süresinin diğer yaş gruplarına göre daha kısa olduğunu öne sürmüştür (9). Çalışmamızda olguların tanı öncesi semptom süresi ortalama $35,28 \pm 56,27$ gün olarak saptandı. Sürenin 0-8 yaş aralığında ortalama $22,05 \pm 21,89$

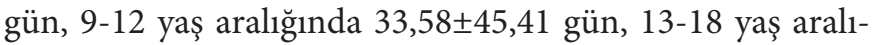
ğında 44,37 $\pm 75,65$ gün olduğu ve literatürle uyumlu olduğu saptandı. Yaş grupları arasında istatistiksel olarak anlamlı fark bulunmadı. Kızlarda semptom başlangıcıyla, hastane başvurusu arasında geçen sürenin ortalama 25,02 $\pm 36,02$ gün, erkeklerde ise $47,48 \pm 72,14$ gün olduğu ve iki grup arasında istatistiksel olarak anlamlı fark olduğu saptandı, kızların puberteye daha erken girmesinin süreci hızlandırmış ve bu süreyi kısaltmış olabileceği düşünüldü.

Bizim çalışmamızda olguların \%4,35'inde hipotiroidi, \%1,09'unda Hashimoto tiroiditi, \%1,09'unda çölyak hastalığı $(\% 1,09)$ eşlik ettiği saptandı. Aydın ve ark. tarafından yapılan bir çalışmada; olguların \%11,9'unda hashimoto tiroiditi, \%10,86'sında çölyak hastalığı eşlik ettiği saptanmıştır (24).

Bizim çalışmamızda olguların tanı anında kan şekeri ortalamasi $442,69 \pm 135,32 \mathrm{mg} / \mathrm{dL}, \mathrm{HbA} 1 \mathrm{c}$ ortalamasi $\% 11,23 \pm 2,53$, C-peptid ortalaması $0,58 \pm 0,95 \mathrm{ng} / \mathrm{mL}$ ve insülin ortalaması $4,56 \pm 5,29 \mathrm{uIU} / \mathrm{mL}$ olarak saptandı. Xin ve ark.'nın yaptığ 1 bir çalışmada; tanı anında kan şekeri ortalaması 376,2 $\pm 154,8$ $\mathrm{mg} / \mathrm{dL}, \mathrm{HbAlc}$ ortalamas $\% 12,7 \pm 2,5$, C-peptid ortalamas1 $0,49 \pm 0,40 \mathrm{ng} / \mathrm{mL}$, insülin ortalaması $3,17 \pm 2,33 \mathrm{mU} / \mathrm{L}$ bulunmuştur (9). Demir ve ark.'nın İstanbul'da yaptıkları

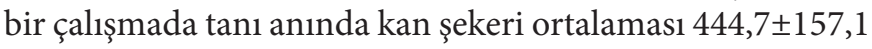
$\mathrm{mg} / \mathrm{dL}, \mathrm{HbA} 1 \mathrm{c}$ ortalaması $\% 10,5 \pm 2,6$ olarak raporlanmıştır (10). Biz de yapılan diğer çalışmalarla benzer sonuçlar elde ettik.

Demir ve ark.'nın yaptıkları bir çalışmada başvuru anında 5 yaş altındaki çocuklarda HbA1c ortalaması \%10,1 $\pm 2,5,6-10$ yaş arası çocuklarda \%10,3 $\pm 2,4,11$ yaş üstündeki çocuklarda \%10,9 2,7 olarak raporlanmıştır. Yine aynı çalışmada kızlarda HbA1c ortalaması \%10,5 $\pm 2,6$, erkeklerde ise $\% 10,4 \pm 2,5$ saptanmış ve cinsiyetler arasında anlamlı fark bulunamamıştır (10). Bizim çalışmamızda 0-8 yaş aralı-

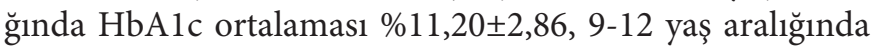
$\% 11,28 \pm 2,33,13-18$ yaş aralığında ise $\% 11,18 \pm 2,62$ olarak 
bulundu. Yaş gruplarıyla ve cinsiyetle $\mathrm{HbA1c}$ düzeyleri arasındaki ilişki incelendiğinde istatistiksel olarak anlamlı fark bulunamadi.

Xin ve ark. tarafından yapılan bir çalışmada DKA ile başvuran olguların kan şekeri ortalaması 446,4 $\pm 165,6 \mathrm{mg} /$ $\mathrm{dL}$, C-peptid ortalaması $0,40 \pm 0,32 \mathrm{ng} / \mathrm{mL}$, DKA ile başvurmayan olguların kan şekeri ortalaması $302,4 \pm 135,0$ $\mathrm{mg} / \mathrm{dL}$, C-peptid ortalamas 1 ise $0,56 \pm 0,45 \mathrm{ng} / \mathrm{mL}$ olarak saptanmıs ve iki grup arasında istatistiksel olarak anlamlı fark bulunmuştur (9). İşleyen ve ark.'nın yaptıkları bir çalışmada; DKA ile başvuran olguların HbAlc ortalaması $\% 12 \pm 2,6$, DKA ile başvurmayan olguların ise $\% 10,4 \pm 3,3$ saptanmış, iki grup arasında istatistiksel olarak anlamlı fark bulunmuştur (25). Bizim çalışmamızda; DKA ile başvuran grupta $\mathrm{HbA} 1 \mathrm{c}$ ortalamas1 \%12,0 $\pm 2,24$, C-peptid ortalamas1 0,32 $\pm 0,30 \mathrm{ng} / \mathrm{mL}$, DKA ile başvurmayan grupta $\mathrm{HbAlc}$ ortalaması $\% 9,96 \pm 2,49$, C-peptid ortalaması 0,96 $\pm 1,37 \mathrm{ng} /$ $\mathrm{mL}$ saptand 1 ve iki grup arasında istatistiksel olarak anlamlı fark bulundu $(\mathrm{p}=0,001)(\mathrm{p}=0,001)$. Yapılan çalışmalarda $\mathrm{HbAlc}$ düzeyinin yüksek olmasının, C-peptit düzeyinin ise düşük olmasının DKA için risk faktörü olduğu gösterilmiştir (26). Diyabetik ketoasidoz ile başvuran olguların kan şekeri ortalaması $457,68 \pm 120,46 \mathrm{mg} / \mathrm{dL}$, insülin ortalamas1 3,33 $\pm 2,42 \mathrm{uIU} / \mathrm{mL}$, DKA ile başvurmayan olguların kan şekeri ortalaması $421,52 \pm 153,27 \mathrm{mg} / \mathrm{dL}$, insülin ortalaması ise $6,31 \pm 7,46 \mathrm{uIU} / \mathrm{mL}$ saptand ve gruplar arasında istatistiksel olarak anlamlı fark saptanmadı.

İşleyen ve ark.'nın yaptıkları bir çalışmada; takip ettikleri olguların \%2,2'sinin metabolik kontrolünün iyi olduğu $(<\% 7,5), \% 97,8$ 'inin kötü olduğu $(>\% 7,5)$ saptanmıştır $(25)$. Bizim olgularımızın \%19,56'sının metabolik kontrolünün iyi olduğunu (<\%7,5), \%80,44'ünün metabolik kontrolünün kötü olduğunu $(>\% 7,5)$ saptadık. Olgularımızın ağırlıklı olarak metabolik kontrolünün kötü olmasının sebebinin daha iyi anlaşılması için; olguların sosyoekonomik seviyeleri, kendilerinin ve ailelerinin eğitim düzeyleri, beslenme ve tedavilerine uyumlu olup olmadıkları, takiplerine düzenli devam edip etmedikleri araştırılmalı ve bu konuda bașka çalıșmalar yapılması gerektiğini düșünüyoruz. Çalışmamızda benzer çalışmalardan farklı olarak olguların yaşadıkları yerlerin merkeze uzaklıklarına bakıldığında \%52,17'sinin 0-50 km uzaklıkta, \%42,39'unun 50-100 km uzaklıkta, \%3,27'sinin 100-150 km uzaklıkta, \%2,17'sinin ise $150 \mathrm{~km}$ 'den daha uzak mesafede olduğu tespit edildi. En çok olgunun merkezden olması nüfus dağılımı ile orantılı olduğunu düşündürdü. Olguların merkeze olan uzaklıkları ve metabolik kontrol durumları arasındaki ilişki incelendiğinde; 0-50 km uzaklıktakilerin \%77,77'sinin, 50-100 km uzaklıktakilerin \%84,84'ünün, $100-150 \mathrm{~km}$ uzaklıktakilerin $\% 66,66$ 'sının, 150 km'den daha uzaktakilerin \%100'ünün kötü metabolik kontrole sahip olduğu saptandı. Biz literatürde bu verileri karşıllaştıracağımız verilere rastlayamadık.
Olgularımızı DKA şiddetine göre sınıflandırarak, tedavilerinde uygulanan protokollere göre DKA'dan çıkış sürelerini kıyasladığımızda; tedavide ISPAD 2018 protokolü uygulanan hafif DKA vakalarının $18,40 \pm 15,96$ saatte, orta DKA vakalarının $18,00 \pm 7,58$ saatte, ağır DKA vakalarının ise $20,20 \pm 12,29$ saatte ketoasidozdan çıtı tokolde diğerlerinden farklı olarak; sıvı tedavisine başladıktan bir saat sonra insülin tedavisine geçilmektedir (7). Biz DKA'dan çıkış süresini bu farklılığın etkilemiş olabileceğini düşünüyoruz.

Bizim çalışmamızın Güney Marmara bölgesinde bu konuda yapılmış olan ilk çalışmalardan birisi olması, olguların merkeze olan uzaklıkları ve metabolik kontrol durumları arasındaki ilişkiyi inceleyen ilk çalışma olması, DKA tedavisinde uygulanan protokollerin DKA'dan çıkış süresine olan etkisinin incelendiği ilk çalışmalardan birisi olması çalışmamızın güçlü yanlarıdır.

Çalışmamızın kısıtlı yönü olgularımızın sosyoekonomik seviyelerinin ve ailelerinin eğitim düzeylerinin çalışmamızda yer almamasidır.

Sonuç olarak biz çalışmamızda Tip 1 DM'nin en sık başvuru semptomlarının poliüri ve polidipsi olduğunu, Tip 1 DM'nin en sık kış ve sonbahar aylarında tanı aldığını, DKA ile başvuran grupta HbAlc düzeyinin daha yüksek, C-peptit düzeyinin ise daha düşük olduğunu gösterdik. Tip 1 DM'de hastaların takibinde bölgesel epidemiyolojik verilerin önemli olduğunu düșünüyoruz. Bizim çalıșmamız da Güney Marmara bölgesinde tanı alıp takip edilen Tip 1 DM'li hastaların verilerini içermektedir. Dolayısıyla araştırmamız bu hastalığın tanı ve takibinde görev alan bölgemizdeki klinisyenlere referans olabilir.

Teșekkür

Yok.

Yazarların Makaleye Katkı Beyanı

Yazarlar eșit katkıda bulunmuștur.

Çıkar Çatıșması

Yazarlar arasında herhangi bir çıkar çatışması yoktur.

Finansal Destek

Çalışma için finansal destek yoktur.

Etik Kurul Onayı

Çanakkale Onsekiz Mart Üniversitesi Tip Fakültesi Klinik Araştırmalar Etik Kurulundan 08.05.2019 tarihli 2011-KAEK-27/20191900054816 saylı onay alınd.

\section{Hakemlik Süreci}

Kör hakemlik süreci sonrasında yayınlanmaya uygun bulunmuş ve kabul edilmiştir. 


\section{KAYNAKLAR}

1. Weber DR, Jospe N. Classification of Diabetes Mellitus. Kliegman RM, Stanton BF, St Geme JW, Schor NF, editors. Nelson Textbook of Pediatrics. 21th ed. Philadelphia: Elsevier Saunders; 2019:11814-11822.

2. Weber DR, Jospe N. Type 1 Diabetes Mellitus (Immune Mediated). Kliegman RM, Stanton BF, St Geme JW, Schor NF, Behrman RE, editors. Nelson Textbook of Pediatrics. 21th ed. Philadelphia: Elsevier Saunders; 2019:11823-11885.

3. International Diabetes Federation. (2019). IDF Diabetes Atlas 9th Edition [Online]. [Çevrimiçi] https://www.diabetesatlas. org/en/

4. Mayer-Davis EJ, Kahkoska AR, Jefferies C, Dabelea D, Balde N, Gong CX, Aschner P, Craig ME. ISPAD Clinical Practice Consensus Guidelines 2018: Definition, epidemiology and classification of diabetes in children and adolescents. Pediatr Diabetes. 2018;19:7-19.

5. Radetti G. Clinical aspects of Hashimoto's thyroiditis. Endocr Dev. 2014;26:158-170.

6. Husby S, Koletzko S, Korponay-Szabó IR, Mearin ML, Phillips A, Shamir R, Troncone R, Giersiepen K, Branski D, Catassi C, Lelgeman M, Mäki M, Ribes-Koninckx C, Ventura A, Zimmer KP; ESPGHAN Working Group on Coeliac Disease Diagnosis; ESPGHAN Gastroenterology Committee; European Society for Pediatric Gastroenterology, Hepatology, and Nutrition. European Society for Pediatric Gastroenterology, Hepatology, and Nutrition guidelines for the diagnosis of coeliac disease. J Pediatr Gastroenterol Nutr. 2012;54(1):136-160.

7. Wolfsdorf JI, Glaser N, Agus M, Fritsch M, Hanas R, Rewers A, Sperling MA, Codner E. ISPAD Clinical Practice Consensus Guidelines 2018: Diabetic ketoacidosis and the hyperglycemic hyperosmolar state. Pediatr Diabetes. 2018;19(27):155-177.

8. American Diabetes Association. 6. Glycemic Targets: Standards of Medical Care in Diabetes-2020. Diabetes Care. 2020;43(Suppl 1):66-76.

9. Xin Y, Yang M, Chen XJ, Tong YJ, Zhang LH. Clinical features at the onset of childhood type 1 diabetes mellitus in Shenyang, China. J Paediatr Child Health. 2010;46(4):171-175.

10. Demir F, Günöz H, Saka N, Darendeliler F, Bundak R, Baş F, Neyzi O. Epidemiologic features of type 1 diabetic patients between 0 and 18 years of age in İstanbul city. J Clin Res Pediatr Endocrinol. 2015;7(1):49-56.

11. Yeşilkaya E, Cinaz P, Andıran N, Bideci A, Hatun Ş, Sarı E, Türker T, Akgül Ö, Saldır M, Kılıçaslan H, Açıkel C, Craig ME. First report on the nationwide incidence and prevalence of Type 1 diabetes among children in Turkey. Diabet Med. 2017;34(3):405-410.

12. Stipancic G, Sepec MP, Sabolic LL, Radica A, Skrabic V, Severinski S, Tiljak MK. Clinical characteristics at presentation of type 1 diabetes mellitus in children younger than 15 years in Croatia. J Pediatr Endocrinol Metab. 2011;24(9-10):665-670.
13. Aras B, Akın A, Ylldırım R, Unal E, Haspolat Y. Tip 1 diyabetes mellituslu çocuklarda tanı anındaki klinik ve laboratuvar bulgularının değerlendirilmesi. Dicle Tip Dergisi. 2019;46(1):11-17.

14. Usher-Smith JA, Thompson MJ, Zhu H, Sharp SJ, Walter FM. The pathway to diagnosis of type 1 diabetes in children: A questionnaire study. BMJ Open. 2015;5:e006470.

15. Zhao Z, Sun C, Wang C, Li P, Wang W, Ye J, Gu X, Wang X, Shen S, Zhi D, Lu Z, Ye R, Cheng R, Xi L, Li X, Zheng Z, Zhang $M$, Luo F. Rapidly rising incidence of childhood type 1 diabetes in Chinese population: Epidemiology in Shanghai during 1997-2011. Acta Diabetol. 2014;51(6):947-953.

16. Güven A, Aydın M. Beş yaşından önce tip 1 diyabetes mellitus tanısı alan çocuklarda etiyopatogenezde rol alan faktörler. Çocuk Sağlığı ve Hastalıkları Dergisi. 2005;48:295-300.

17. Gamble DR, Taylor KW. Seasonal incidence of diabetes mellitus. Br Med J. 1969;3:631-633.

18. Klingensmith GJ, Tamborlane WV, Wood J, Haller MJ, Silverstein J, Cengiz E, Shanmugham S, Kollman C, WongJacobson S, Beck RW; Pediatric Diabetes Consortium. Diabetic ketoacidosis at diabetes onset: Still an all too common threat in youth. J Pediatr. 2013;162(2):330-334.

19. Demir K, Büyükinan M, Dizdarer C, Şimşek D, Özen S, Asar G, Can Ş, Altıncık A, Özhan B, Ersoy B, Böber E, Darcan Ş. Tip 1 diyabetli çocuklarda tanıda diyabetik ketoasidoz sıklığı ve ilişkili faktörler. Güncel Pediatri. 2010;8(3):52-55.

20. Dabelea D, Rewers A, Stafford JM, Standiford DA, Lawrence JM, Saydah S, Imperatore G, D’Agostino RB Jr, Mayer-Davis EJ, Pihoker C; SEARCH for Diabetes in Youth Study Group. Trends in the prevalence of ketoacidosis at diabetes diagnosis: The SEARCH for diabetes in youth study. Pediatrics. 2014;133(4):938-945.

21. Wolfsdorf J, Glaser N, Sperling MA; American Diabetes Association. Diabetic ketoacidosis in infants, children, and adolescents: A consensus statement from the American Diabetes Association. Diabetes Care. 2006;29(5):1150-1159.

22. Neu A, Willasch A, Ehehalt S, Hub R, Ranke MB; DIARY Group Baden-Wuerttemberg. Ketoacidosis at onset of type 1 diabetes mellitus in children-frequency and clinical presentation. Pediatr Diabetes. 2003;4(2):77-81.

23. Neu A, Ehehalt S, Willasch A, Kehrer M, Hub R, Ranke MB. Varying clinical presentations at onset of type 1 diabetes mellitus in children-epidemiological evidence for different subtypes of the disease? Pediatr Diabetes. 2001;2(4):147-153.

24. Aydın H, Andıran N, Buluş D, Yağlı E. Tip 1 diyabetes mellituslu hastaların klinik, laboratuvar, sosyokültürel ve demografik özellikleri. Turkish J Pediatr Dis. 2016;2:112-119

25. İşleyen F, Bolu S. Adıyaman ilindeki diyabetik çocukların epidemiyolojik özellikleri. Güncel Pediatri. 2019;17(1):1-16.

26. Komulainen J, Lounamaa R, Knip M, Kaprio EA, Akerblom HK. Ketoacidosis at the diagnosis of type 1 (insulin dependent) diabetes mellitus is related to poor residual beta cell function. Arch Dis Child. 1996;75(5):410-415. 